\title{
Program Evaluation for Community Learning Centers as Community Learning Resources in Ambon City
}

\author{
Lambertus J. Lokollo, Zulfiati Syahrial, Soepriyanto
}

\begin{abstract}
The general study objective is to figure out and describe the effectiveness of PKBM implementation as learning resources in Ambon Municipality. This research is evaluation research based on the CIPP evaluation model (Context, Input, Process, Product). The objective of the research is the PKBM program as a center of community learning resources in the city of Ambon, using a qualitative approach. This approach has superiority that provides a comprehensive study of social phenomena conducted by researchers. The research method is used as a guideline or tool to help researchers on how the steps of the research are carried out, as an effort to reveal research problems. The outcomes of the study show that: (1) the role of The manager, learning community, the organization in supporting the learning process of the Package C program in PKBM in the city of Ambon is good. (2) Managers, and learning residents, PKBM learning material in the city of Ambon is good. (3) Managers and learning residents, the learning methods used by tutors in learning the Cpackage program at PKBM in Ambon City are good. (4) Managers and learning residents, the use of learning tools and media by tutors in learning the $C$ package program at PKBM in Ambon city is good. So it can be concluded that all aspects considered to be in a good category, so it can be decided that the aspects of the process are in a good category.
\end{abstract}

\section{Keywords: Program Evaluation, PKBM, Process Evaluation}

\section{INTRODUCTION}

In the framework of community development, various empowerment efforts have been carried out by the government and the private sector which are aimed at individuals, groups and communities. The empowerment effort is to about the increasingly high demands on the world of work that requires the best quality of human resources or society. To answer the need for intelligent and quality human resources, education plays an important role. The 1945 Constitution states that one of the goals of the independence of the Indonesian nation is to educate the lives of the nation. The revelation of the 1945 Constitution concerning education was stated in Law No. 20, in 2003 article 3 states that national education purposes developing the capability and shape of honorable national character and civilization to teach the lives of the nation, directing to develop the potential of students to become faithful and

Revised Manuscript Received on September 22, 2019.

Lambertus J. Lokollo, Post Graduated Universitas Negeri Jakarta. lambertuslokollo@gmail.com.

Zulfiati Syahrial, Profesor at Universitas Negeri Jakarta. Zulfiati Syahrial

Soepriyanto, Lecturer at Universitas Terbuka Jakarta. Soepriyanto. fearful people of God.

The still high dropout rate in Indonesia can be seen from the statistical data issued by the Ministry of Education and Culture's Education and Culture Data and Statistics Center:

Dropout rates in Maluku Province can be seen from the following statistical data:

Pic. 1: School Dropout Figures in Maluku Province 2016/2017

Maluku is the province with the highest Open Unemployment Rate (TPT) in August 2017 followed by Banten, West Java, North Sulawesi and Riau Islands Provinces. The Central Statistics Agency (BPS) noted that the number of jobless people in Maluku reached 65,735 people or 9.29 per cent of the total workforce of 707,796 people. The number of unemployed people in Maluku in August 2017 increased by 13,372 people compared to the position in August 2016. While the population which constituted the workforce and work actually decreased by 48,725 people to 642,061 people.

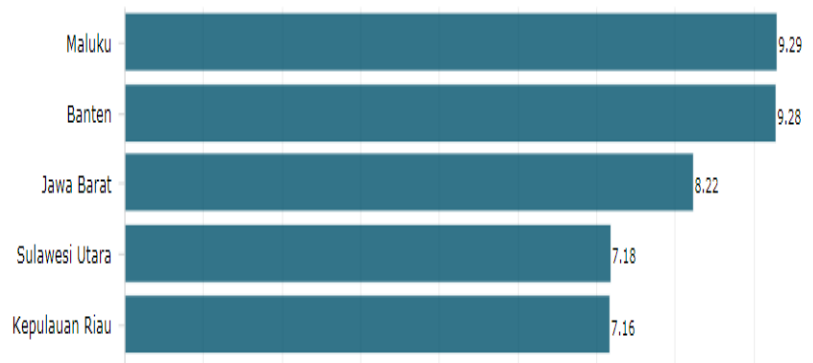

Pic. 2: Provincial Open unemployment rate in Indonesia in 2017 
This problem needs to be overcome through the implementation of non-formal education that can accommodate students who drop out of school, or unemployed due to the level of skills possessed is not the demands of the workforce. Non-formal learning in the context of the national education system also has the same task as other education (formal education) which is to provide the best service to the community, especially the target community of non-formal education. The objective of non-formal education is not just to deal with the poor and ignorant (underdeveloped, blind primary education, drop out) formal education, but the target of non-formal education continues to expand as per the development of science and technology and the development of employment, changing society especially related to the culture of the community itself, as Sharma's (2014: 87-101) research shows that local educational institutes outside the official structure can generate a variety of learning choices and opportunities, replying to the different requirements of countryside communities who live in situations that While the results of Su and Feng's research (2014: 219-226) show that the existence of community learning resource centres that are held non-formally can positively encourage lifelong learning.

PKBM is a place for community learning practices that are concentrated on empowering the community by learning as per the learning requirements and potential of the community in achieving progress in education, economics, social culture and other aspects of life. Ministry of Education and Culture (2012: 30), this reflects PKBM functions as (1) conducting learning activities, (2) coordinating in utilizing the potential of the community, (3) presenting information, (4) exchanging information and knowledge, and (5) become a place for efforts to increase knowledge, skills, attitudes and certain values for citizens who need it. For this reason, PKBM as part of non-formal education organizes education programs outside of school, which consists of two main activities, namely: (1) learning activities, such as equality education programs, literacy education, early childhood education, life skills education and youth education or courses, and women's education; and (2) non-learning activities such as TBM (community reading parks), KUB / Pre-cooperative activities, art and productive businesses of PKBM.

In Ambon City (Ambon City Education Office 2018), there are nine institutions of Community Learning Centers (PKBM) spread across Nusaniwe District 3, Sirimau 3 District, Teluk Ambon District 1, and Baguala District 2. Of the 9 PKBMs, all have been having National School Principal Number (NPSN).

Based on data from the Ambon City Education Office, in the 2017 / 2018-2018 / 2019 school year

\begin{tabular}{llll}
\hline No. & Name PKBM & \multicolumn{2}{l}{$\begin{array}{l}\text { Amount } \\
\text { Learning Citizens }\end{array}$} \\
\hline & & $\mathbf{2 0 1 7 / 2 0 1 8}$ & $\mathbf{2 0 1 8 / 2 0 1 9}$ \\
1 & Anggrek Indah & 79 & 76 \\
2 & Bougenville & 95 & 124
\end{tabular}

$\begin{array}{llll}3 & \text { Different } & 52 & 57 \\ 4 & \text { Makmur Jaya } & 70 & - \\ 5 & \text { Nsia'ir } & 363 & 439 \\ 6 & \text { Dewa-Dewa Dewi } & 40 & 90 \\ 7 & \text { SKB Kota Ambon } & 155 & 109 \\ 8 & \text { Kamboja } & 66 & 7 \\ 9 & \text { Pelangi } & - & 97 \\ \text { Amount } & 920 & 999\end{array}$

The data above shows that PKBM in Ambon City can absorb a large number of learning citizens. This shows that PKBM in Ambon City has a significant role in supporting the 12-year compulsory education program by providing space for students who drop out of school to continue their education.

Evaluation comes from the word evaluation (English), which means assessment. Evaluation experts formulate various definitions of evaluation with different formulations, but the core or the contents are the same, namely giving material consideration about achieving a goal and used in decision making.

\section{LITERATURE REVIEW}

Daniel L. Stufflebeam (1986: 159) said that evaluation is a process of describing, obtaining, reporting and determining descriptive information and for a consideration of whether or not and useful or not something based on the purpose, planning, implementation, and implications that can be used to take a decision, fulfill accountable needs, and can maintained for improvement.

This definition describes a comprehensive evaluation starting from how the evaluation process is carried out, and what are the objectives to be achieved, and what are the benefits for users/stakeholders. This evaluation focuses on the process, object, purpose, and benefits of the evaluation results

Jean A. King and Laurie Stevahn (2013: 13) said that evaluation is a systematic investigation process to offer good information about the features, activities, or results of a policy for valuable purposes.

This definition views evaluation as a systematic scientific process. The task of the evaluator in this definition is not only to look for information about the object being evaluated, more than that, the task of evaluator's work is to provide any information except information about the object being evaluated. So it only focuses on the evaluation process and object.

Louis Cohen, (et.all) (2010: 185) also said that Evaluation is' the provision of information on issues' which is based and from which decisions for action are taken '. Evaluation is' providing information about the specific issues that underlie the assessment and from which decisions are made). This definition states that the benefits of evaluation to obtain accurate information whether the policies in carrying out a program or policy have been taken with the correct procedure and basis, and focusing on usability. 
Mathison and Fournier (2010: 49) said that Evaluation is a process of applied inquiry to collect and synthesize evidence culminating in final decisions about the state, value, propriety, appropriateness, significance, or quality of a program, product, person, policy, proposal, or plan. This definition describes the stages of the evaluation process, the objectives to be achieved, and what objects can be evaluated. It focuses on the evaluation process and objectives.

Furthermore, Donna M. Mertens (2009: 1) defined evaluation as a systematic technique for defining propriety, appropriateness, or value of a policy program, activity, technology or similar entity to provide information in decision making about the entity.

According to Wirawan (2012: 17) To find out how far and what part of the program objectives that have been achieved and which parts of the program purposes have been accomplished, and what are the causes, it is necessary to evaluate the program. The program is everything a person tries to do in the faith of getting outcomes or effect. The program is an activity or activity designed to implement the policy and carried out for an unlimited time. According to Arikunto et al. (2006: 4) There are three important meanings and need to be emphasized in determining the program, namely: (1) employment of a policy, (2) occur in a relatively long time-not a single activity, but plural, and (3) occurs in organizations that involve a group of people. While The Join Standards on Educational Evaluation (1997: 7-8) defines the program as "activities that are provided continuingly." However, the program is not only defined as a set of activities, but more than that, the program is; a set of activity plans that are arranged systematically; using resources; achieve a goal (goal); based on need; having specificity, identified, interested by a group or individual; in a specific context; have documented results as outputs, outcomes, and impacts; and has a reliable follow-up system.

According to the Trias Teknodik Manager in Sukardi (2014: 4); programs are some educational activities that are provided regularly).

\section{Fig 3. Programs Assessed}

The PKBM program is a program that is planned and arranged systematically, which aims to prepare to learn citizens to be able to be independent (empowered), have good attitudes and skills and be able to develop the standard of life both socially and economically, sensitive to the problems that occur in their environment and able to solve the problem. The basic principles for developing and compiling PKBM programs include: (1) the programs developed must expand so that learning citizens have the opportunity to freely develop experiences, knowledge, skills, attitudes and values related to ethics, aesthetics, logic, and kinesthetics during learning, (2) the program must have a balanced principle, where each competency developed in the PKBM program must be achieved through sufficient time allocation for an effective learning process; (3) the programs developed by PKBM must be relevant, because each program is related to preparing learning citizens to improve the quality of life through opportunities, experiences and training in acting and acting responsibly in realizing the maturity of thinking of learning citizens, (4) the programs developed by PKBM must be able to prioritize differentiated processes, principles this is an effort of the player Individuals where learning citizens must understand: what needs to be learned, how to think, how to learn and do to develop their own potential and needs optimally.

Non-formal education in the implementation of its programs has a very varied institutional management model. The unit models that are built depend heavily on the needs of the program, the target students and the importance of program development. The small size of the institutional management unit model and the extent of the target developed are largely determined by the ability of the developer (provider) to understand the types of programs to be built. This institutional management model is like study groups, study groups, course institutions, training institutions and community learning centres or PKBM.

The Center for Community Learning Activities (PKBM) is an educational institution that was born from the idea of awareness of the importance of the position of the community in the process of developing non-formal education. Therefore, the establishment of PKBM amid the community is expected to be the backbone of the development process through empowering the potential in the community. Sitepu (2014: 153) PKBM is an educational institution formed by the community, government or society in collaboration with the government, began to develop in Indonesia in early 1998 driven by the economic crisis that hit Indonesia which caused many people to lose their jobs and experience severe economic difficulties. Programs organized are tailored to the requirements and potential of the local public.

PKBM as one of the government's work partners in educating the lives of the people (nation) through non-formal education programs is expected to be able to foster a learning society so that it will increase independence, education and innovation in finding new information to improve their lives. PKBM as a learning centre, it is built based on community needs by focusing on self-help, mutual cooperation and community participation, especially about the importance of increasing the capacity, skills or intelligence of community members.

To better understand PKBM in relation to its function and role to improve the ability, skills and intelligence of the community, several things related to it are needed, including: (a) PKBM definition, (b) PKBM roles and functions, (c) Characteristics PKBM, and (d) PKBM as a source of community learning.

Published By: 
According to Maimun (2016: 62); the CIPP program evaluation model was chosen about this research. CIPP evaluation contains four kinds of decisions, namely: (1) planning decisions, namely decisions that affect the selection of program goals and objectives (maintaining existing, modifying, and developing); (2) Structuring decisions, which are decisions that ensure the strategy and design procedures to achieve the goals that have been set before; (3) Implementing decisions, namely decisions that provide procedures for implementing programs and improving the designs, methods and strategies chosen; (4) Recycling decisions, namely decisions that determine whether the activity or program itself needs to be continued, revised, and terminated.

According to Farnas Dan Ali (2016: 571-579), The selection of the CIPP evaluation model is based on the consideration that the CIPP evaluation model is among the most effective systematic models based on management that focuses on the effectiveness and quality of the education system. In addition, according to Asfaroh et al (2017: 1999-2010) the CIPP model is also effective for formative and summative evaluation and for obtaining decisions and problem solving where this evaluation model considers a program as a system, so that evaluation of the program as a system must be carried out in detail based on components components included in the model.

Zhang et al. (2011: 57) in more detail, suggests that the evaluation model can support to recognize the requirements of students, service providers and the community. The input evaluation component can help explain that needs are well identified, process evaluation components monitor processes and possible procedural barriers, while product components measure, interpret, and assess results, feasibility, value, significance, programs.

\section{METHODOLOGY/MATERIALS}

The general research objective is to find out and describe the effectiveness of PKBM implementation as learning resources in Ambon Municipality. This research is evaluation research (evaluation research) based on the CIPP evaluation model (Context, Input, Process, Product) with the object of research is the PKBM program as a centre of community learning resources in the city of Ambon, using a qualitative approach. This approach has superiority that provides a comprehensive study of social phenomena conducted by researchers.

According to Sugiono (2008: iii) In general, research methods can be classified into three, namely qualitative-quantitative methods, and research and development methods. Creswell stated that qualitative research is a procedure of scientific study to recognize human difficulties in a social framework by creating a complete and multifaceted picture that is presented, reporting a detailed view of the sources of information, and carried out in natural settings without any intervention from researchers.

\section{RESULTS AND FINDINGS}

Process evaluation is an evaluation that aims to assess the implementation of a predetermined plan. This evaluation detects or predicts deficiencies in the design procedures for program activities and also to determine the extent to which a plan has been implemented, whether the plan is by work procedures, and what must be corrected. In other words, process evaluation is an evaluation activity to identify whether or not there is compatibility between planning and implementation, as well as informing each programmable decisions, recording and assessing each activity related to the program implemented.

Evaluation of the process of implementing the PKBM program as a community learning resource center in Ambon City, covering aspects of a) program planning process, b) program implementation and c) supervision of the learning process.

\section{A. Program Planning}

Planning is the first step to determine the success of program implementation. The dimensions of the package $\mathrm{C}$ program equality planning aspects include 1) recruitment of learning citizens and 2) selection and formation of study groups.

\section{1) Recruitment of Learning Citizens}

One of the basic principles of implementing the Package $\mathrm{C}$ program is to expand the service of opportunities to obtain an education for the community that is not taught in the formal education pathway. The target is people who cannot complete their education at the secondary education level (SMA / MA), people who stop at the end of secondary education before obtaining a diploma (dropout), or the community that stops at the primary education level (SMP / MTs).

Generally, the community groups mentioned above come from groups of people who are economically weak, which requires them to work earlier so that they view education as not a top priority. Encouraging community members who drop out of school to continue their education is not an easy thing, so to deal with it requires a good plan.

Related to the recruitment pattern applied by PKBM in Ambon City in capturing the prospective learning citizens of the Package C program, Dra said. Laila Sikdewa, PKBM Dewa-god manager, as follows: In general, the recruitment of students for the equality education package program is performed in two steps, the first is socialization, and the second is the registration of learning citizens. Finding citizens learning the Paket $\mathrm{C}$ program is quite difficult because generally community members who have stopped school are reluctant to continue their education. The strategy we undertook to capture members of the community to join our program was to first collect data from the community who dropped out of school through the data contained in the local village government and gather them in a meeting with us to present figures who considered influential in the community to give them an understanding of the

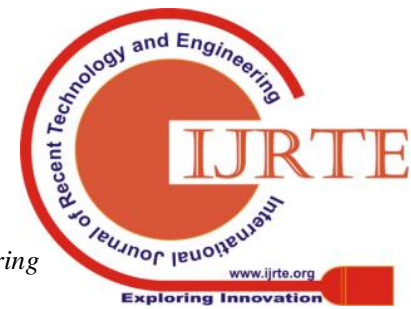


importance of education. This character's role is very important because their words, policies or decisions will usually be followed by community members. The next step is to accept the registration of prospective learning citizens. We are trying to make this registration process as easy and flexible as possible but still without violating the rules and regulations. The conditions that must be taken at the time of the registration are only the latest diploma or report card and the photo, then when registering the prospective learning residents fill out the registration form and a statement of ability to join the program to completion. This strategy we feel is quite successful because every year, we can organize at least two study groups.

Based on the information above, the recruitment process of learning citizens of the Package $\mathrm{C}$ program on PKBM in the city of Ambon has been well planned by the PKBM manager. With an effective recruitment pattern, this package C program can continue every year. This pattern of socialization involving community leaders and socialization through various media does not only provide information to the community, but both PKBM institutions and community members benefit from the information.

\section{2) Selection and Formation of Study Groups.}

The process of selecting and placing learning citizens is very important in forming a study group. In addition to preventing the behavior of some prospective learning residents who want to quickly pass by directly registering to sit in high class, with the correct selection process prospective learning citizens can be placed by their initial competencies and abilities so that they do not experience difficulties in following the learning process.

Related to the selection process and the formation of a group learning program $\mathrm{C}$ package on PKBM in Ambon City, Drs. Marten Kullen, N.Siair PKBM manager, stated as follows:

The formation of the study group in the package $\mathrm{C}$ program was carried out through identification stages, selection and data collection of prospective learning citizens. After identifying the documents submitted by prospective learning citizens at the time of registration. The criteria that we use is that the study group for class $\mathrm{X}$ is a prospective student studying in Package B / SMP / MTs or students who drop out of school in class $\mathrm{X}$, the study group for class $\mathrm{XI}$ is a prospective learning citizen who dropped out of school in class XI and the group studied for class XII is a prospective learning citizen who dropped out of school in class XII. Also, we also do a placement test. Test questions consist of questions for classes $\mathrm{x}, \mathrm{x}$, and xii. Based on the documents of prospective learning residents and the results of these tests, we then place and form study groups which usually consist of 20-30 learning citizens in each class.

Based on the information above the Package $\mathrm{C}$ program study group planning on PKBM has been carried out systematically and by the applicable rules and regulations. Thus, it can be concluded that the plan of program $\mathrm{C}$ package on PKBM in Ambon City has been done well.

\section{B. Program Implementation}

Evaluation of the implementation of parcels $\mathrm{C}$ education program on PKBM in the city of Ambon is explained based on instructional dimensions that have a role and contribution in providing sufficient learning experience during the Package $\mathrm{C}$ program on PKBM in Ambon City. This evaluation includes instructional dimensions including 1) the role of the organization in supporting the learning process, 2) presentation of material (content), 3) learning methods (methods), and 4) utilization of media (facilities).

\section{1) Organizational Role}

Evaluation of the role of the organization in supporting the learning process contains indicators: a) the role of the manager in the PKBM program, b) the attitude of the manager towards the implementation of the PKBM program, c) the role of tutors in learning, d) the smooth administration of PKBM programs and e) procurement tools/facilities for the PKBM program

To see the role of the organization in supporting the occurrence of effective learning processes, the researchers distributed questionnaires to tutors, managers, and learning citizens to respond according to the reality they experienced. Based on the outcomes of the questionnaire, the evaluation results, as shown in Figure 4, are obtained:

Fig 4. Role of the organization in supporting the learning process

Based on the assessment of learning citizen tutors on indicators related to the role of organizations in supporting the implementation of the learning process, it can be seen that the perception of tutors, managers, and residents learning about the role of the organization is in the range of the category very well, with the mean rating tutor on the organizational role of PKBM Dewa-Dewa $=3.95$, PKBM Makmur Jaya $=3.94$, PKBM N. Siair $=3.44$, and PKBM Cambodia $=3.07$, with a total average of 3.60. PKBM manager assessment shows the mean score on PKBM Gods $=3.80$, PKBM Makmur Jaya =3.80, PKBM N. Stair = 3.60, and PKBM Cambodia $=3.60$. With a total average of 3.45 , while the results of the assessment of the learning community showed a mean score on PKBM Gods $=3.72$, PKBM Makmur Jaya $=3.58$, PKBM N. Siair $=3.49$, and PKBM Cambodia $=3.60$. With a total average of 3.45. The total average of the overall score is 3.50 , which means that according to the tutors, 
managers, and learning residents, the role of the organization in supporting the learning process of the Package $\mathrm{C}$ program in PKBM in the city of Ambon is good.

\section{Learning material (Content)}

Assessment of learning material in PKBM in Ambon city was obtained through questionnaires distributed to tutors, managers, and PKBM learning residents including the following indicators: 1) coverage of learning material in achieving learning citizen competencies, 2) material benefits for learning citizens, 3 ) material relevance to the competencies that must be achieved in the PKBM program, 4) learning experience gained from the presentation of Learning material, 5) completeness in the discussion of Learning material, 6) The attractiveness of the material for learning citizens, 7) Suitability of the material to the needs of the learning community, 8 ) Systematic presentation of Learning material, 9) Use of examples or illustrations in clarifying learning material, and 10) Meaning of training in clarifying Learning material.

The assessment results of tutors, managers and residents learning about indicators of learning materials in PKBM in Ambon City are presented in the form of images as follows:

Fig 5 Assessment of learning materials in the Package C program

Based on the tutor's assessment, PKBM managers and residents learned indicators about learning materials in PKBM in Ambon City as shown in the figure above, it can be seen that the adequacy of the learning material in PKBM in Ambon City was in the range of the good category, with the mean rating tutor of learning material on PKBM Deities = 3.40, PKBM Makmur Jaya = 3.65, PKBM N. Siair = 3.28, and PKBM Cambodia $=3.97$, with a total average of 3.57 . PKBM manager assessment shows the mean score on PKBM Deity $=3.60$, PKBM Makmur Jaya $=4.00$, PKBM N. Stair $=$ 3.28 , and PKBM Cambodia $=3.00$. with a total average of 3.45 , while the results of the assessment of the learning community showed the average score on PKBM Gods = 3.29, PKBM Makmur Jaya $=3.55$, PKBM N. Siair $=3.45$, and PKBM Cambodia $=3.00$. with a total average of 3.32 . The total mean overall score is 3.45 , which means that according to tutors, managers, and learning residents, PKBM learning material in Ambon city is good.

3) Learning Methods (Methods)

Assessment of the learning methods used by tutors in learning the PKBM C package program in Ambon city was obtained through questionnaires distributed to tutors, managers, and PKBM learning residents including the following indicators: a) accuracy in determining the method of giving learning material, $b$ ) the suitability of the method with the characteristics of the learning community, c) the suitability of the method with the learning material, d) the suitability of the method with the allocated time, e) the suitability of the method with the place/space used, f) the suitability of the method with the given exercise/task, g) suitability methods with competencies to be achieved, and h) variations in tutors in media voters.

The assessment results of tutors, managers and residents learn about indicators of tutor learning methods in PKBM in Ambon City presented in the form of images as follows:

Fig 6. Assessment of learning methods used by tutors in learning

Based on the assessment of tutors, PKBM managers and residents learn indicators about the learning methods used by tutors in PKBM in Ambon City as shown in the picture above, it can be seen that the use of tutoring methods in PKBM in Ambon City is in the range of categories that are very good, with details of the average tutor's assessment of the learning method used in PKBM Deity $=3.38$, PKBM Makmur Jaya $=3.76$, PKBM N. Siair $=3.18$, and PKBM Cambodia $=2.92$, with a total average of 3,31 . PKBM manager assessment shows the mean score on PKBM Dewa $=3.00$, PKBM Makmur Jaya =4.00, PKBM N. Stair = 3.00, and PKBM Cambodia $=3.00$. With a total average of 3.25 , while the results of the assessment of the learning community showed an average score on PKBM Gods $=3.31$, PKBM Makmur Jaya $=3.31$, PKBM N. Siair $=3.31$, and PKBM Cambodia $=3.38$. With a total average of 3.32. The average total overall score was 3.29 which means that according to tutors, managers, and residents learning, the learning method used by tutors in learning the $\mathrm{C}$ package program at PKBM in Ambon city is good.

4) Utilization of Learning Tools and Media (Facilities)

Assessment of the use of learning tools and media in learning on the PKBM C package program in Ambon city was obtained through questionnaires distributed to tutors, managers, and PKBM learning residents including the following indicators: a) selection of media/learning support tools by tutors, b ) selection of media / supporting tools with existing electricity capacity, c) selection of media / supporting tools with time allocated, d)

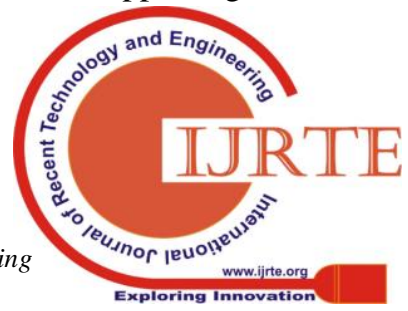


selection of media / supporting tools with table and chair facilities, e) selection of media / supporting tools with infrastructure, f) optimization utilization of media/support tools by tutors, g) utilization of media with systematic teaching materials, h) how to operate media / supporting tools, i) accuracy in the presentation of learning materials using media / supporting tools, and j) accuracy in doing exercises/assignments with using tools/media

The results of the assessment of tutors, managers and citizens learning about indicators of the use of learning media in a package $\mathrm{C}$ program by PKBM tutors in Ambon City are presented in the form of images as follows:

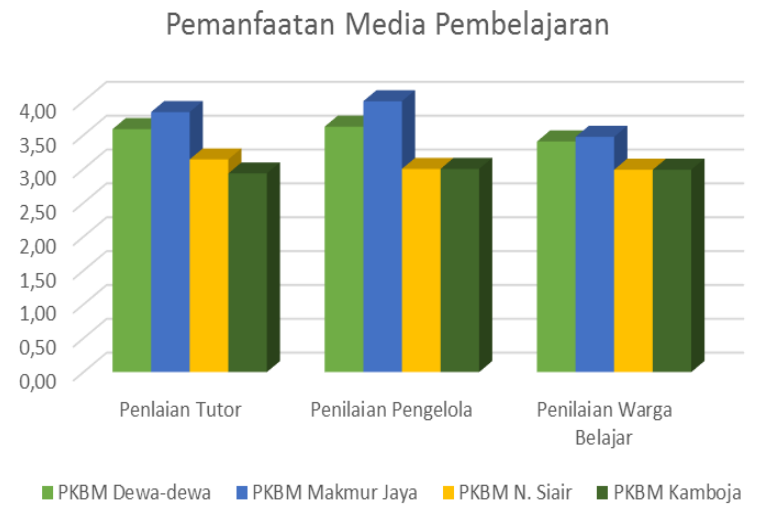

Fig 7 Assessment of the use of tools and media in the learning process

Based on the assessment of tutors, PKBM managers and residents learn indicators about the use of tools and learning media by tutors in PKBM C package learning program in Ambon City as shown in the picture above, it can be seen that the use of tools and media by tutors is in the good category range very good, with details of the average tutor's assessment of the learning method used in PKBM Dewa-Dewa $=3.59$, PKBM Makmur Jaya $=3.84$, PKBM N. Siair $=3.14$, and PKBM Cambodia $=2.93$, with total average 3.38. PKBM manager assessment shows the mean score on PKBM Gods = 3.63, PKBM Makmur Jaya $=4.00$, PKBM N. Stair $=3.00$, and PKBM Cambodia $=3.00$. With a total average of 3.41, while the results of the assessment of the learning community showed an average score on PKBM Gods $=3.41$, PKBM Makmur Jaya $=3.47$, PKBM N. Siair $=$ 3.99, and PKBM Cambodia $=2.99$ with a total average of 3.21. The total average overall score is 3.33 which means that according to tutors, managers, and learning residents, the use of learning tools and media by tutors in learning the $\mathrm{C}$ package program at PKBM in Ambon city is good.

\section{c. Supervision of the Learning Process}

PKBM managers must supervise the learning process. Supervision is used to observe and know the implementation of the learning plan with its implementation., Also, supervision is to find out whether the learning process is effective and implemented effectively and on target.

Supervision of the learning process in the Package $\mathrm{C}$ program on PKBM in Ambon City is explained by Drs. Marten Kullen, N.Siair PKBM manager: Supervision of the learning process in the package $\mathrm{C}$ program is carried out in the form of monitoring and supervision. Monitoring of the learning process starts from planning, implementing, and evaluating learning outcomes, either by direct monitoring by not interfering with the learning process, as well as by looking at documents owned by teachers such as learning devices, attendance lists, class journals, and so on.

The explanation above illustrates that PKBM managers in Ambon City have supervised the learning process in package $\mathrm{C}$ equalization programs through monitoring, supervision and reporting. This transparent and objective monitoring and supervision covers all stages of the learning process, starting from the stages of planning, implementing, and evaluating learning outcomes of PKBM learning citizens. Supervision activities are carried out by PKBM managers and supervision teams from the Ambon City Education Office, whose results are reported regularly to follow up and assess whether the program is right on target. Thus, it can be concluded to support the improvement of the quality of education on an ongoing basis PKBM managers have supervised the learning process of package $\mathrm{C}$ programs well.

\section{DISCUSSION}

Discussion of the components of the PKBM program implementation process as a community learning resource center in Ambon City, covering aspects of a) program planning process, b) program implementation and c) supervision of the learning process.

Program planning is needed in determining strategies to achieve the objectives of effective program implementation programs and efficient use of resources. Program planning answers the question of what needs to be done, when, where, by whom, and how. To maintain the sustainability of institutions and programs that PKBM organizes, it must have an effective system of recruitment of learning citizens, because the problem of lack of adequacy of learning citizens and numbers is one of the problems often faced by PKBM. The results of this study indicate that PKBM in Ambon City implements an effective recruitment system, as evidenced by the number of study residents who tend to be stable from year to year.

In the process of implementing learning, managers, tutors, and learning citizens assess that the organization has a good role in supporting the learning process both in the administration and in the procurement of tools/facilities for the PKBM program. Fast and efficient administrative services supported by the availability of adequate facilities can increase the motivation to teach lecturers and the learning motivation of learning citizens and encourage the development of innovative, creative, effective and fun learning processes in PKBM in Ambon City. This is in line with the opinion of Jonathan Kozol (2010: 185) that, "all the school on earth reforms are worthless if they have to come to school in buildings that destroy their spirits". This opinion means that all forms of school reform on the surface of the earth are in vain if when they come to school, students get school buildings that destroy their learning spirit.

The assessment of managers, tutors, and learning 
residents is in the range of a good category about the adequacy of learning materials (learning materials) on PKBM in Ambon City. Learning material is one of the important components of a good learning system that is deliberately tightened (by design) and materials that can be used (by utilization), namely materials obtained from the normal world every day. According to Kapfer and Kapfer (1972: 48), explains that learning materials or learning resources are the basic components needed to facilitate student learning. Therefore, tutors are required to be able to adjust learning materials that can accommodate the needs of each learning citizen to be used to build their knowledge.

Thus it can be concluded that the management and utilization of learning material (materials) in the form of textbooks, audiovisuals, computer software, etc. are designed for teachers as learning aids (instructional aid) or learning aids for students (learning aids) to facilitate the achievement of learning objectives in the implementation of package $\mathrm{C}$ program learning in the city of Ambon has been good.

In addition to being required to design and modify learning materials that are by the needs of the learning community, tutors are also required to continuously innovate regarding their methods or ways of delivering the material to the learning community. This is as stated by Cronbach and Snow as quoted by Ronald R. Sims and Serbrenia J. Sims (1998: 62) as follows: The educator has always developed and applies new instructional treatments, hoping for improved results. He is the best method of instruction for a given purpose. Since learners differ, the search for generally superior methods should be supplemented by a search for ways to fit the instructions to each kind of learner. One can expect interaction between learner characteristics and instructional methods. Where these exist, the instructional approach is not the best for all persons.

The above opinion means that educators must continually strive to design and apply new forms of treatment to get better results. This is the best teaching method for a specific purpose. Because of the different characteristics and abilities of learners, the teacher must be able to use a variety of learning methods and adapt the methods he uses for each student because there is not one of the most effective learning methods that can be used for everyone.

According to Reigeluth (1983: 14), "instructional methods are the different ways to achieve different outcomes under different conditions"; Instructional methods are different ways to achieve different results and conditions. Reigeluth groups are learning methods into three types, namely pengoranisasian (organizational), delivery (delivery), and management (management). Organizing strategy is an elemental method to regulate subject-matter content that has been selected for learning; the delivery strategy is a method to deliver material or to receive and respond to input from students, while management strategy is an element to make decisions about organizing components and delivery that will be used during the learning process.

The results of this study indicate that based on the assessment of managers, tutors, and learning residents the learning methods used by the average tutor showed excellent scores, both in organizing methods, conveying, and managing methods that will be used to convey learning material. According to the manager, tutors and learning residents choose the method in conveying the learning material is appropriate, by the characteristics of the learning community, and the time and place provided and carried out varied and using the right learning media.

Technology and media play an important role in providing learning experiences. According to Smaldnino, the design and use of learning media are very important because learning media facilitate student interaction with materials that produce and strengthen actual learning. If the ingredients are weak, not properly structured, or poorly sorted, only limited learning will occur. On the other hand, learning media that are strong and well-designed are experienced in such a way that they can be easily encoded, stored, remembered, and used in various ways. Students will remember this material if they are created, integrated, and presented in a way that allows them to have the needed impact.

The results of this study found that the assessment of managers, tutors and learning residents was in the very good category related to the use of learning tools and media in learning PKBM package $\mathrm{C}$ program in the city of Ambon regarding the selection of media/learning support tools by tutors, media selection / tools supporter with existing electricity capacity, selection of media / supporting tools with time allocated, selection of media / supporting tools with table and chair facilities, selection of media / supporting tools with infrastructure, optimization of utilization of media / supporting tools by tutors, utilization of media with systematic material teach, h) how to operate media / supporting tools, accuracy in the presentation of learning material using media / supporting tools, and accuracy in doing exercises / tasks using tools / media.

The implementation of package $\mathrm{C}$ program in achieving the stated goals requires supervision and evaluation in order to obtain a decision whether the program needs to be continued, repaired or stopped, this is as the definition proposed by Worthen and Sanders (1975: 20) says that, "evaluation as a process (Program evaluation is a process of identifying and gathering information to assist decision-makers in choosing various alternative decisions).

The results of this study indicate that PKBM managers in Ambon City have supervised the learning process in the package $\mathrm{C}$ equalization program through monitoring, supervision, and reporting. This transparent and objective monitoring and supervision covers all stages of the learning process, starting from the stages of planning, implementing, and evaluating learning outcomes of PKBM learning citizens. Supervision activities are carried out by PKBM managers and supervision teams from the Ambon City Education Office, whose results are reported regularly to follow up and assess whether the program is right 
on target. Thus, it can be concluded to support the improvement of the quality of education on an ongoing basis PKBM managers have supervised the learning process of package C programs well.

Based on the description of the aspects of the process component (PKBM evaluation process) in Ambon City, it can be concluded that all aspects that are considered to be in a good category, so it can be decided that the aspects of the process are in a good category.

\section{CONCLUSION}

PKBM in Ambon City implements an effective recruitment system, as evidenced by the number of study citizens who tend to be stable from year to year. In the process of implementing organizational learning has a good role in supporting the learning process, both the smooth administration and the procurement of tools/facilities for the PKBM program. Fast and efficient administrative services supported by the availability of adequate facilities can increase the motivation to teach lecturers and the learning motivation of learning citizens and encourage an innovative, creative, effective and fun learning processes

Management and utilization of learning materials in the form of textbooks, audiovisuals, computer software, etc. designed for teachers as learning aids (instructional aid) or learning aids for students (learning aids) to facilitate the achievement of learning objectives in the implementation of package $C$ learning program in the city of Ambon has been good, as well as the learning method used by the average tutor shows excellent scores, both in organizing methods, conveying, and managing methods that will be used to convey learning material supported by media selection/tools learning support by tutors, selection of appropriate and good media/tools

In the supervision aspect of the learning process and results, PKBM managers in Ambon City have supervised the learning process in the package $\mathrm{C}$ equalization program through monitoring, supervision and reporting. This transparent and objective monitoring and supervision covers all stages of the learning process, starting from the stages of planning, implementing, and evaluating learning outcomes of PKBM learning citizens, carried out periodically by PKBM managers and supervision teams from the Ambon City Education Office.

Based on the description of the aspects of the process component (PKBM evaluation process) in Ambon City, it can be concluded that all aspects that are considered to be in a good category, so it can be decided that the aspects of the process are in a good category.

\section{ACKNOWLEDGEMENTS:}

This research work is supported by Pattimura University.

\section{REFERENCES}

[1] Arikunto, Suhasini dan Cepi Saffrudin Abdul Jabar. Evaluasi Program Pendidikan Pedoman Teoretis Praktis Bagi Mahasiswa dan Praktisi Pendidikan. Jakarta: Bumi Aksara Cet. ketiga 2009,

[2] Andrea Honigsfeld and Audrey Cohan, Breaking the Mold of School Instruction and Organization: Innovative and Successful Practices for the Twenty-first Century, (Maryland: The Rowman \& Littlefield. Inc., 2010

[3] Creswell W. Jhon. Research Design: Pendekatan Kualitatif, Kuantitatif, dan Mixed. Cetakan III. Yogyakarta: Pustaka Belajar, 2013.
[4] Charles M. Reigeluth, Instructional Design Theories and Models: An Overview of Their Current Status (New Jersey: Lawrence Erlbaum, 1983

[5] Data Pendidikan Kesetaraan, Dinas Pendidikan Kota Ambon, 2018.

[6] Donna M. Mertens, Research and evaluation in education and psychology: integrating diversity with quantitative,qualitative, and mixed methods, California: Sage Publication, 2010

[7] Transformative research and evaluation, New York: Guilford Press, 2009.

[8] Farnaz Limouei and Omid Ali Hoseinzadeh, An Internal Evaluation of Educational Groups in Dentistry Faculty of Tabriz Medical University Using CIPP model in 2015, International Journal of Medical Research \& Health Sciences, (2016), Vol. 5 (11)

[9] Guili Zhang, et.al., Using the Context, Input, Process, and Product Evaluation Model (CIPP) as a Comprehensive Framework to Guide the Planning, Implementation, and Assessment of Service-learning Programs, Journal of Higher Education Outreach and Engagement, Vol $15,(4),(2011)$

[10] Jean A. King, and Laurie Stevahn, Interactive Evaluation Practice: Mastering The Interpersonal Dynamics Of Program Evaluation,.California: Sage Publication,2013.

[11] Jodi L. Fitzpatrick et.al., Program Evaluation: Alternative Approaches Practical Guidelines. New York: Longman, 1997

[12] Kementerian Pendidikan dan Kebudayaan, Ikhtisar Data Pendidikan Tahun 2016/2017, (Jakarta: Pusat Data dan Statistik Pendidikan dan Kebudayaan, 2017), h. 26

[13] Louis Cohen, (et. all), A guide to teaching practice: revised edition, New York: Routledge, 2010

[14]

[15] Mustofa, Kamil. Pendidikan Nonformal. Pengembangan Melalui Pusat Kegiatan Belajar (PKBM) di Indonesia. Bandung: Alfabeta, 2011.

[16] Maimun. Evaluasi Program Parenting Pada Program Pendidiksan Anak Usia Dini (PAUD) di Kota Mataram. Disertasi PPS-TP UNJ, 2016

[17] Philip G. Kapfer, Miriam B. Kapfer, Learning Packages in American Education, (New Jersey: Educational Technology Publication, 1972

[18] Ronald R. Sims nd Serbrenia J. Sims. The Importance of Learning Styles: Understanding The Implications for Learning, Course Design, And Education

[19] Standard dan Prosedur Penyelenggaraan Pusat Kegiatan Belajar Masyarakat (PKBM) Jakarta: Kementerian Pendidikan dan Kebudayaan, 2012

[20] Stufflebeam Daniel L, and Anthony J. Shinkfield. Systematic Evaluation: A Self-Instructional Guide to Theory and Practice. Dordrecht: Kluwer-Nijhoff Publising, 1986.

[21] Sukardi. Evaluasi Program Pendidikan dan Kepelatihan. Jakarta: Bumi Aksara, 2014.

[22] Sitepu, B.P, Pengembangan Sumber Belajar, Jakarta: PT RajaGrafindo Persada, 2014

[23] Sugiyono, Metode Penelitian Pendidikan: Pendekatan Kuantitatif, Kualitatif dan R\&D (Bandung: Alfabeta, 2008

[24] Tanka Nath Sharma, Education for Rural Transformation: The Role of Community Learning Centers in Nepal. Journal of Education and Research, Vol. 4, No. 2, 2014

[25] Wirawan, Evaluasi Teori Model, Standard, Aplikasi dan Prosesi (Contoh Aplikasi Evaluasi Program: Pengembangan Sumber Daya Manusia, Program Nasional Pemberdayaan Masyarakat (PNPM), Mandiri Pedesaan, Kurikulum, Perpustakaan, dan Buku Teks (Jakarta: RadjaGrafindo Persada, 2012),

[26] Worthen, B.R. and J.R. Sanders. Educational Evaluation: Theory and practice. 1975.

[27] Yahui Su and Liyia Feng, Community Service as a Lifelong Learning Practice: Themes and Hypotheses, International Journal of Humanities and Social Science, Vol. 4 No. 4. 2014.

\section{AUTHORS PROFILE}

I am Lambertus J. Lokollo, affiliated with Post Graduated Universitas Negeri Jakarta. For contact pleases contact at lambertuslokollo@gmail.com.

My name is Zulfiati Syahrial, Profesor at Universitas Negeri Jakarta. Zulfiati Syahrial. My area of interest is community learning.

I am Soepriyanto, and Lecturer at Universitas Terbuka Jakarta. Soepriyanto. 